臨界領域における気液平衡関係

\title{
－BWR 式の適用性についての検討*—
}

平田 光穗**, 須田精二郎**，宮下 礼子**，星野 俊男***

Vapor-Liquid Equilibrium Relations in the Critical Region

- Some Discussion on the Availabilities of BWR Equation*-_

by Mitsuho Hirata, ${ }^{* *}$ Seijiro Suda, ${ }^{* *}$ Reiko Miyashita** and Toshiro Hoshino***

\begin{abstract}
Summary : Vapor-liquid equilibrium behaviors in the critical regions were estimated for the propane-nbutane binary system, using the BWR equation of state and its modified forms of Edmister and Orye.

Discussions were focused on the possibility of estimating the vapor-liquid equilibrium relations near the critical points of the binary mixture. The reproducibility of the equation for PVT relations of pure substances in their saturated state was also discussed in some detail for pure propane and $n$-butane.
\end{abstract}

\section{1 緒 言}

従来， 2 成分系炭化水素混合物の臨界領域に扔ける気液平衡 関係に関する実測值の報告は少なく，また推算についてもこの 領域における推算法や精度について検討を加えた例は少ない。 笔者らは新たに製作した高圧気液平衡測定装置 ${ }^{(0)}$ を用いて，プ ロパンーn-ブタン系など二，三の 2 成分系炭化水素混合物につ いて臨界領域下の気液平衡関係を実測したり.10)。

これら実測結果より，特にプロパンーnーブタン 2 成分系の結 果をもとにして，従来から高圧に㧍ける多成分系の気液平衡関 倸の推算式としてよく知られている Benedict-Webb-Rubinの 状態方程式 (以後 BWR 式と略す) とその代表的な修正式で ある Orye" および Edmister ら について，プロパンーn-ブタン 2 成分系の臨界領域下における 気液平衡関係を推算する場合の適用性について険討した。

\section{BWR 式およびその修正式}

BWR 式 ${ }^{2), 3)}$ は物質個有の 8 定数を含む状態方程式であり， 一般的な表示形は次のとおりである。

$$
\begin{aligned}
P= & R T d+\left(B_{0} R T-A_{0}-\frac{C_{0}}{T^{2}}\right) d^{2} \\
& +(b R T-a) d^{3}+a d d^{6} \\
& +\frac{c d^{3}}{T^{2}}\left(1+r d^{2}\right) \operatorname{EXP}\left(-r d^{2}\right)
\end{aligned}
$$

多成分系の気液平衡関係の推算の際には, 次のような泥合則 が用いられる。

* 昭和 46 年 2 月 26 日受理

** 東京都立大学工学部 (東京都世田谷区深沢 2-1-1) Faculty of Engineering, Tokyo Metropolitan University (21-1, Fukazawa, Setagaya-ku, Tokyo)

*** 東亜石油侏式会社 Toa Oil Co., Ltd.

$$
\left.\begin{array}{ll}
B_{0}=\left[\sum_{i} B_{0 i} x_{i}\right] & a=\left[\sum_{i}\left(x_{i} a_{i}{ }^{1 / 3}\right)\right]^{3} \\
A_{0}=\left[\sum_{i}\left(x_{i} A_{0 i}{ }^{1 / 2}\right)\right]^{2} & c=\left[\sum_{i}\left(x_{i} c_{i}^{1 / 3}\right)\right]^{3} \\
C_{0}=\left[\sum_{i}\left(x_{i} C_{0 i}{ }^{1 / 2}\right)\right]^{2} & \alpha=\left[\sum_{i}\left(x_{i} \alpha_{i}^{1 / 3}\right)\right]^{3} \\
b=\left[\sum_{i}\left(x_{i} b_{i}{ }^{1 / 3}\right)\right]^{3} & r=\left[\sum_{i}\left(x_{i} r_{i}^{1 / 2}\right)\right]^{2}
\end{array}\right\}
$$

BWR 式の修正式の一つである Orye" による修正式は，従 来の BWR 定数の $A_{0}$ に系個有の $M_{i j}$ なる值を加えることに より修正を施したもので，これにより $A_{0}$ の混合則は，

$$
A_{0}=\sum_{i} x_{i}{ }^{2} A_{0 i}+\sum_{\substack{i \\ j \neq i \\ j>i}} \sum_{j} M_{i j} x_{i} x_{j} A_{0 i}{ }^{1 / 2} A_{0 j} j^{1 / 2}
$$

と表わされる。

Edmister ら゙によって発表された修正 BWR 式はさきの BWR 式を一般化したものであって，その中で一般化 BWR 定

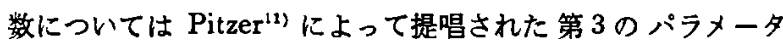
一，偏心因子 $(\omega)$ を用いて式化している。

$$
\left.\begin{array}{rl}
P_{r}= & T_{r} d_{r}+\left(B_{0}{ }^{\prime} T_{r}-A_{0}{ }^{\prime}-\frac{C_{0}{ }^{\prime}}{T_{r}{ }^{2}}\right) d_{r}{ }^{2}+\left(b^{\prime} T_{r}-a^{\prime}\right) d_{r}{ }^{3} \\
& +a^{\prime} \alpha^{\prime} d_{r}{ }^{6}+\frac{c^{\prime} d_{r}{ }^{3}}{T_{r}{ }^{2}}\left(1+r^{\prime} d_{r}{ }^{2}\right) \operatorname{EXP}\left(-r^{\prime} d_{r}{ }^{2}\right) \quad(4) \\
r^{\prime}= & 0.052058-0.09064 \omega+0.10506 \omega^{2} \\
c^{\prime}= & 0.035694+0.185297 \omega-0.230125 \omega^{2} \\
a^{\prime}= & 0.0235866+0.290284 \omega-0.295413 \omega^{2} \\
b^{\prime}= & 0.0275404+0.131009 \omega-0.134924 \omega^{2} \\
C_{0}^{\prime}=0.098224+0.401236 \omega-0.0397267 \omega^{2} \\
A_{0}{ }^{\prime}=0.343258-0.127521 \omega-0.509131 \omega^{2} \\
a^{\prime} \alpha^{\prime}=0.0000875 \\
B_{0}=0.113747+0.127349 \omega-0.243280 \omega^{2}
\end{array}\right\} \quad(5)
$$

\section{3 純粋物質に対しての BWR 式の適用性}

ます筆者らは，プロパンーnーブタン 2 成分系の構成成分であ 
るプロパンおよび nーブタンの各純粋物質について，これらの 枹和領域に対しての BWR 式の適用性を検討した。純粋物質が 気液平衡状態にあるとき，次の 2 式を $T_{L}=T_{V}$ の条件下で满 足している。

$$
\begin{aligned}
& P_{L}{ }^{0}=P_{V^{0}} \\
& f_{L}{ }^{0}=f_{V}{ }^{0}
\end{aligned}
$$

ここで $P_{L^{0}}$ は飽和状態での液相の圧力, $P_{V}{ }^{0}$ は同じく蒸気 相の圧力であり，また $f_{L}{ }^{0}, f_{V}{ }^{0}$ はおのおの飽和状態での液相, 蒸気相のフガシチである。

そこで，BWR 式の適用性についての検討方法としては， BWR 式が純粋物質の飽和状態において式 (6) と（7）を満 足するかとうか，またそれらの計算值が実測值とどのような関 俰にあるかを調べることにした。実測值として採用したデータ はプロパン, nーブタンともに Canjar のデータ集犻に搡録され ているものを用いた。また BWR 定数についてはプロパン， n-ブタンともに Benedict らによって発表された定数 ${ }^{3)}$ を使用 した。

圧力に関しての検討では，飽和状態に㧍ける気相および液相 の実測密度 $\left(d_{V}{ }^{0}, d_{L}{ }^{\circ}\right)$ 加ら BWR 式，および Edmister らの 一般化 BWR 式により気液両相の圧力 $\left(P_{V}{ }^{0}, P_{L}{ }^{0}\right)$ を臨界点ま で計算した。Fig. 1 にプ ロパンに関しての計算值と 実測值を示す。BWR 式に よれば計算される圧力は 2 組あって, それぞれ液相と 蒸気相に対応する圧力とし て求められる。そのなか で，蒸気相について算出さ れる $P_{V}{ }^{0}$ は，いずれの物 質についても実測値とよい 一致を示すことが知られ た。一方, 液相の圧力 $P_{L}{ }^{0}$ はプロパンの臨界点近くで は実測値および蒸気相の圧 力 $P v^{0}$ とよく一致してい るが, 対臨界温度 $\left(T_{r}\right)$ が およそ 0.98 より小さくな る温度範囲では両相の圧力

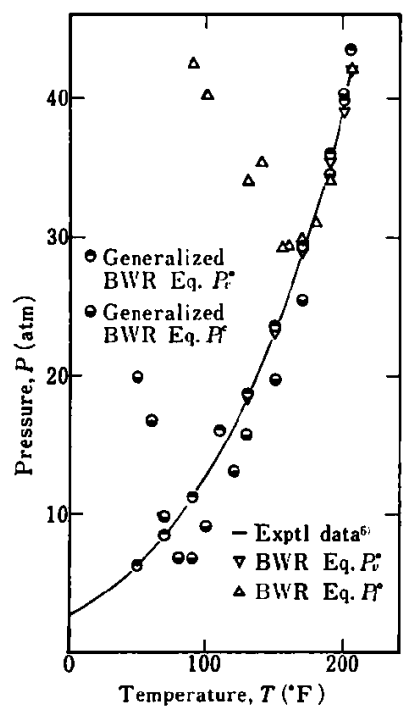

Fig. $1 P$ vs. $T$ Plots of Propane は一致しなくなる。また，一般化BWR式による計算において む $P_{L}^{0}$ は $T_{r}<0.98$ では $P_{V}{ }^{0}$ と一致しなくなる。このこと は，n-プタンについても局様であって，一般にいわれているよ うにBWR式が飽和湤相の性質をもうまく表現しえるというこ ととは矛盾することがわかった。

次に純粋物質の飽和状態における第 2 の条件，すな⿰力口式 （7）について調べた。今度も圧力の場合と同様にして $d_{V}{ }^{0}$ と $d_{L}{ }^{0}$ から, BWR 式により蒸気相拉よび液相のフガシチ $\left(f_{V}{ }^{0}\right.$, $\left.f_{L}{ }^{0}\right)$ を式 (8) により計算し, そのフガシチ比 $\left(f_{V^{0}} / f_{L}{ }^{0}\right)$ の 挙動をみた。

$$
\begin{aligned}
R T \ln f= & R T \ln R T d \\
& +2\left(B_{0} R T-A_{0}-\frac{C_{0}}{T^{2}}\right) d \\
& +\frac{3}{2}(b R T-a) d^{2}+\frac{6}{5} a \alpha d^{5}
\end{aligned}
$$

$$
\begin{aligned}
& +\frac{c d^{2}}{T^{2}}\left[\frac{1}{r d^{2}}-\left(\frac{1}{r d^{2}}-\frac{1}{2}-r d^{2}\right)\right. \\
& \left.\times \operatorname{ExP}\left(-r d^{2}\right)\right]
\end{aligned}
$$

プロパンおよびnブタンのフガシチの比 と $T r$ との関係を,

Fig. 2 に記す。フガ シチ比が 1 となるのは 臨界点にごく近いとこ ろで，T，が 0.9 より 小さい低温側になると 式（7）が满是されな くなっている。液相の 密度について, 式(7) が満足されない範囲を みると,プロパンでは 臨界密度の約 1.8 倍以 上，nーブタンでは約 1.9 倍以上となってい る。BWR 式より計算 されたプロパンの $f_{V}{ }^{0}$ と $f_{L}{ }^{0}$ おび実測值を Fig. 3 中で比較する と, 奏測値と $f_{\boldsymbol{V}}{ }^{\circ}$ は相 対誤差 2\% 以内で一致 しているが, $f_{L}{ }^{0}$ は低 温になるほど、これら の值からすれていて BWR 式が液相のフガ シチの再現性にそしい ことを示しているとい える。

次に BWR 式によ りプロパンおよび

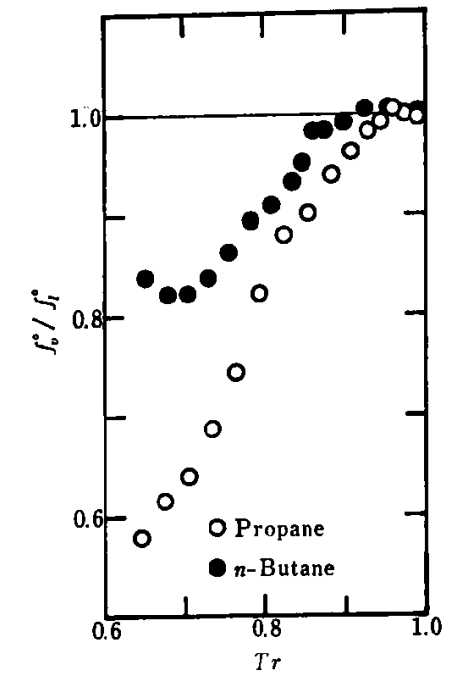

Fig. $2\left(f_{v}^{0} / f_{l}^{0}\right)$ vs. $T_{r}$ Plots

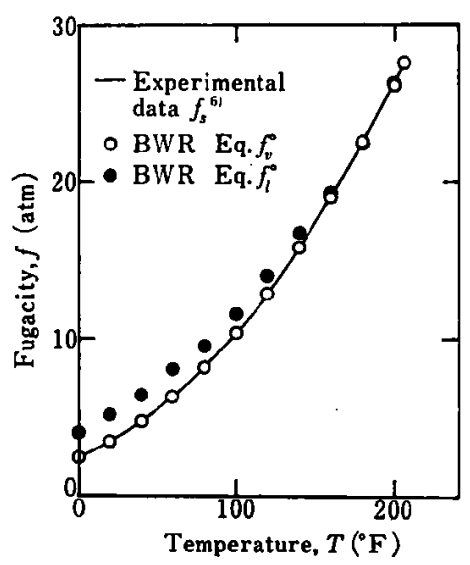

Fig. $3 f$ vs. $T$ Plots of Propane nーブタンのおのおのについてさきの式 (6) と（7）が同時に 満足されるような圧力対温度関係を求めてみた。つまり，BWR 式により新たに飽和蒸気圧曲線を描かせ，これを実測の館和蒸 気圧曲線と比較した。このよ5にして求めた圧力 $\left(P_{\mathrm{cal}}\right)$ は同 温の飽和蒸気压より 1〜2 psia ほど大きい值で，相対的なずれ はプロパンに対しては 4\%，n-ブタンに対しては $2 \%$ 内に納 まった。またこのとき, 計算により求めた密度 $\left(d_{\mathrm{ca} 1}\right)$ は, 液 相については計算值は実測値より小さく，気相については計算 值は実測值より大きく，その相対的なずれは低温になるほど大 きく、およそ $3 \%$ にのぽる。飽和状態での温度と密度との関保 は Fig. 4 のごとく $d_{\mathrm{cal}}$ は実測値の内側にある。また,この 計算において $T r$ が 0.95 を越えるようになると，蒸気相の密 度を Newton 法により求める際に，Newton 法の欠点である “浮気性”のために本来の蒸気密度を求めることができず，ご く臨界点近くまでの圧力の計算は無理となった。さきに述べた ように $d_{L}{ }^{0}$ より BWR 式から計算した圧力 $P_{L}{ }^{0}$ は低温側で は夷測および計算によって得られた飽和蒸気圧 $P_{\text {cal }}$ からだい 
ぶずれている。これは 液相側で圧力対密度曲 線が急な傾きをなして いるために、さきに述 ベたよ5に 2, 3\% ほ どの密度の変化が大き く圧力の值に影響を与 えるものと考えた。ま た,プロパンに関して $P_{V}{ }^{0}$ は実測蒸気圧と $0.6 \%$ の平均相対登差 で一致しているが, $P_{\text {cal }}$ は実測值と 19 台 の誤差をもっており，

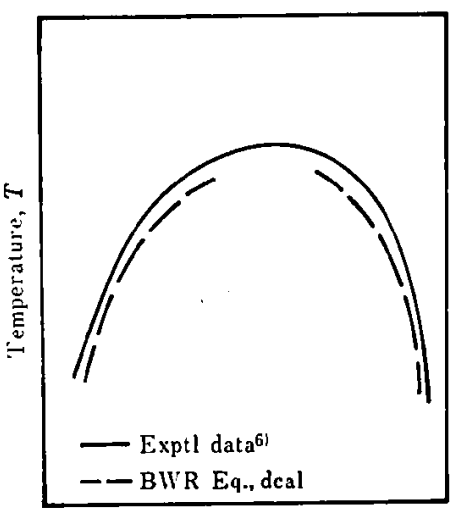

Density, $d$

Fig. $4 \quad T-d$ Diagram
実測の蒸気圧をよく再現するのは, やはり $d_{v}^{0}$ から BWR 式 により計算された場合であることが知られた。nープタンについ ても同様のことがいえる。

臨界領域における気液平衡関係の推算には，一方の棈成成分 の政界点を越えた領城においてるその物斦の仮想的な飽和状热 の物性を求めなければならない場合がある。そこで，次に各純 粋成分の臨界点を越えた領城でのフガシチを式 (8)により計 算し，奏測值との比較を行なってみた。臨界点を越えた領城で 飽和蒸気压曲線上の圧力対温度関係を外そうして求めた特定の （温度, 圧力）状態において，式 (8)により計算されたフガシ

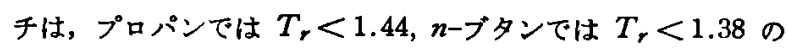
籁囲においてそれぞれ相対誤差 1\%，2\% 以内で実測値々一致 した。そこで, Benedict $ら^{2), 3}$ の定数を用いた BWR 式は臨 界点を越えていても真の臨界点の近傍であれば，実測值をよく 再現すると考えてよい。

\section{4 プロパンーnーブタン 2 成分系混合物に対する BWR 式の適用性}

プロパンーn-ブタン 2 成分系の気液平衡関係の実測值として は，筆者らののデータのほかに Kay ${ }^{7}$ のもの，および Nysewander, Sage, and Lacey') によるものがある。これらの実測 值をもとにして, 2 成分系混合物の気液平衡関係の推算に対し てさきの式 (2) の混合則を用いた BWR 式が 2 成分系の臨 界条件を満足するかどうかについて調べた。実測の臨界密度, 臨界温度そして臨界組成から式 $(1)$ により臨界圧 $\left(P_{c}\right)$ を計 算した。その結果と実測值との比較を Fig. 5 に示した。Kay の実測に関して $P_{c}$ の計算値と害測值との差は最大 $0.23 \mathrm{~atm}$ であり，各点における相対誤差は平均 $0.23 \%$ となる。また, Nysewander らの実測に関しては, 計算值と実測值との差は最 大 $0.34 \mathrm{~atm}$ であり，相対誤差は平均 $0.46 \%$ になる。これらの 結果から BWR 式がいま着目しているプロパンーnープタン 2 成 分系混合物の臨界点をかなりよく再現していることがわかる。

ただし，本法のような実測の $d_{c}, T_{c}$ および $x_{c}$ (または $y_{c}$ ） を用いて $P_{c}$ を算出する方法はあくまです便法であって純粋に BWR 式による臨界値の推算法ではないことに注意すべきであ る"1。

次に本 2 成分采について, Kay ${ }^{7}$, Nysewander ら ${ }^{8)}$ の文献 值と BWR 式によって推算される值との比較を行なってみた。

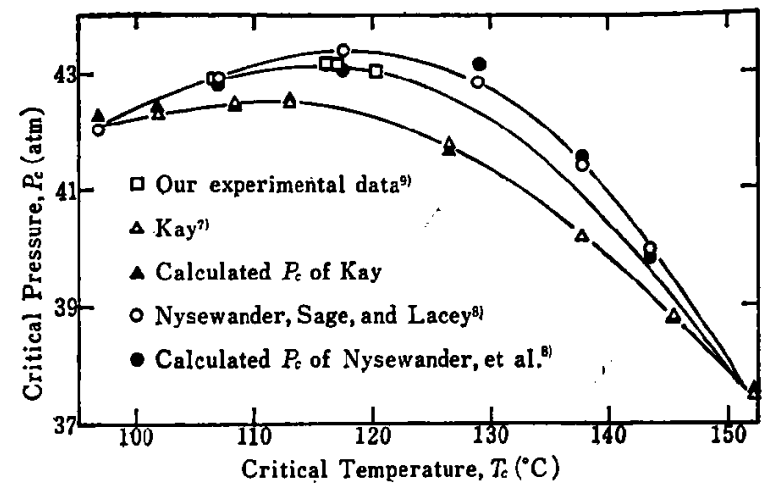

Fig. $5 T_{c}$ vs. $P_{c}$ Plots for the System Propane-n-Butane

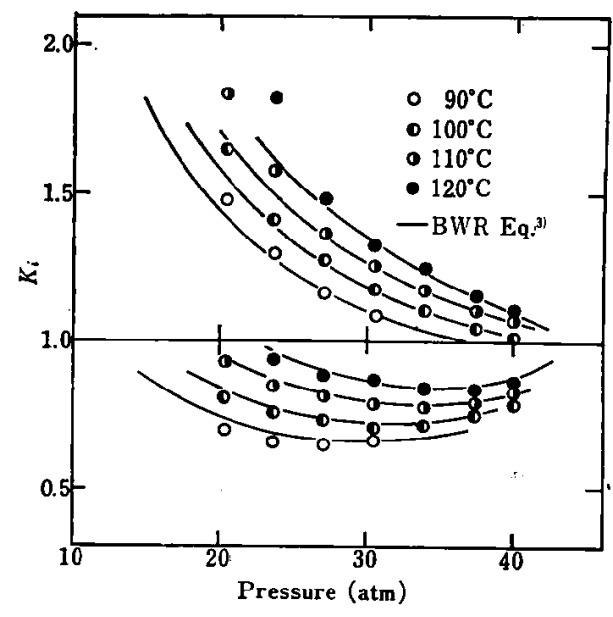

Fig. $6 \quad K_{i}$ vs. $P$ Plots of Kay's Data

Kay の等温データは $90,100,110$ および $120^{\circ} \mathrm{C}$ であるが, この実測值と推算結果とを比較すると Fig. 6 のようによい一 致がみられる。しかし Nysewander ら”の実測值と推算值との 関係は，等温データでは高温になるほど，推算值は実測值から 大きくずれている。Nysewander ら は露点一沸点測定方式によ る測定を行なっており，臨界点およびその周辺の実測は行なっ ていない。したがって，それらの值は実測値から作図上の外そ らによって求めたものであって，その間に誤差が導入されてい るものと推測される。一方, $\mathrm{Kay}^{7}$ は同し露点-沸点測定方式 による測定でありながら, 実際に臨界点を観察しているので, それだけ臨界点近くでの実測值の信頼性は高くなっていると考 えてよい。

次に本 2 成分系についての筆者らの実測值に基つく推算結果 について述べる。筆者らの等温データは $106.53^{\circ} \mathrm{C}$ と 120.29 ${ }^{\circ} \mathrm{C}$ についてのもので Fig. 7, 8 に $120.29^{\circ} \mathrm{C}$ の実測值と BWR 式, Orye の修正 BWR 式, 挹よび Edmister らの一般化 BWR 式による推算結果を示す。

偏心因子を用いた一般化 BWR 式によれば， $120.29^{\circ} \mathrm{C}$ の状 態下の気液平衡関係をむとの BWR式そのものよりもさらによ い精度で推算できることが示された。

Orye の修正 BWR 式による推算結果と筆者らの実測值との 比較を Fig. 9, 10 に示す。 $120.29^{\circ} \mathrm{C}$ の本系の $\mathrm{K}$-value 対 $X_{1}$ のプロットにおいて，修正 BWR 式における $M_{i j}$ の值をごく せまい範囲で変化させた時の推算の経過を示した。本系の場合 


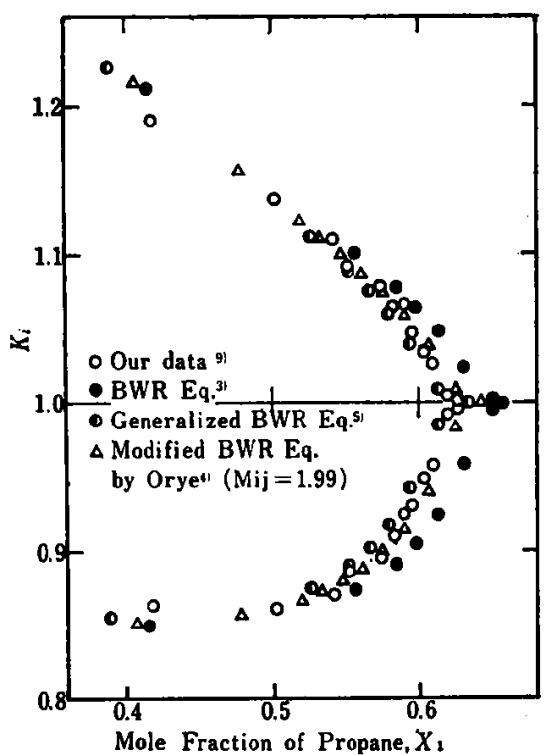

Fig. $7 K_{i}$ vs. $X_{1}$ Plots of the System Propane$n$-Butane at $120.29^{\circ} \mathrm{C}$

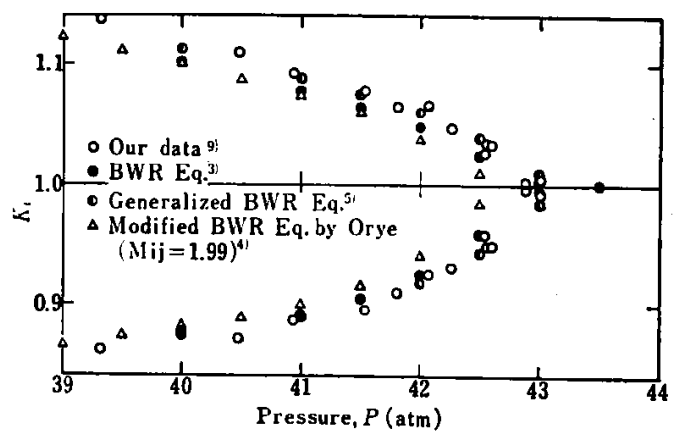

Fig. $8 K_{i}$ vs. $P$ Plots of the System Propane$n$-Butane at $120.29^{\circ} \mathrm{C}$

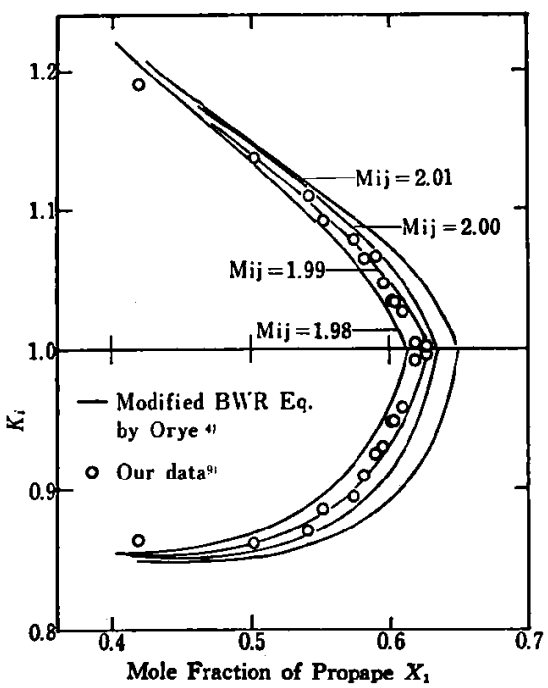

Fig. $9 K_{i}$ vs. $X_{i}$ Plots of the System Propane$n$-Butane at $120.29^{\circ} \mathrm{C}$

は, $M_{i j}$ の值の変化は臨界点化近くなるほと $\mathrm{K}$-value に大き な変化を及ぼし，臨界点から離れるほと， $M_{i j}$ の変化は Kvalue に影䈏しなくなる。

プロパンーn-プタン 2 成分系の $120.29^{\circ} \mathrm{C}$ の $\mathrm{K}$-value 対 $X_{1}$

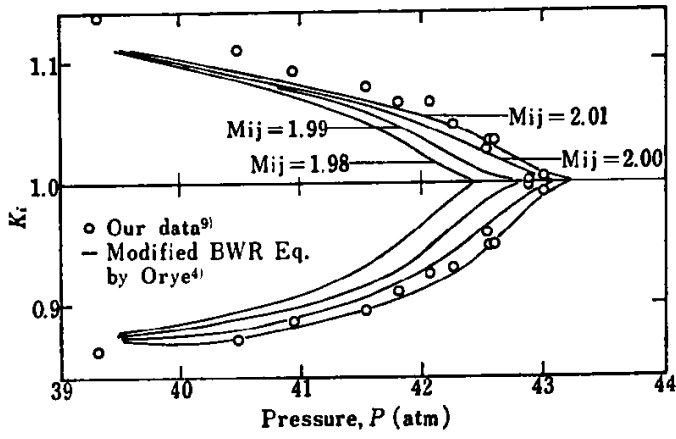

Fig. $10 K_{i}$ vs. $P$ Plots of the System Propane$n$-Butane at $120.29^{\circ} \mathrm{C}$

のプロットでは実測值を再現する $M_{i j}$ の值は 2.0 より小さい とみられるが，一方，K-value 対圧カのプロットでは逆に $M_{i j}$ が 2.0 上り大きい值で実測值を再現する。このことから， ある特定の系に関して 1 個の $M_{i j}$ の值を用いて串測值を再現 させることは不可能であることが見いだされた。

以上, BWR 式によるプロパン-nーブタン 2 成分系の臨界領 域下に打ける気液平得関保の推算に対寸る適用性について検討 したが，この系では，BWR 式拉よびその修正式による推算結 果がかなりよく実測值と一致していることが知られた。

\section{5 結 音}

プロパンーnープタン 2 成分系泿合物の臨界領域下における気 液平衡関保を筆者, $\mathrm{Kay}^{21}$ ，そして Nysewander ら の゙゙ータ をもとにして，BWR 式光,3) および Orye の修正式”と Ed-

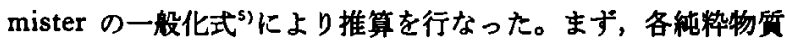
について，盷和領域あるいは臨界点以上の領域において BWR 式が適用できるかどうかについて調べたが，液相側に BWR 式 を適用することは不適当であることがわかった。

また，本 2 成分系気液平衡関係の推算においては次の上5な ことが知られた。まず，BWR 式による臨界領域下の気液平衡 関係で，臨界点周辺での推算が不可能といえない場合があり， 本采の $120.29^{\circ} \mathrm{C}$ では BWR 式により推算もでき，かつ実测 值をかなりよく再現することができる。次に，Orye の修正 BWR 式による推算では $M_{i j}$ の值が臨界点周辺で大きく推算 結果似影響を及ぼす。そして 1 個の $M_{i j}$ の值で実測值を再現 することは不可能であることが知られた。

記 号

$A_{0}, B_{0}, C_{0}, a, b, c, \alpha, \gamma=\mathrm{BWR}$ 式の 8 定数

$A_{0}{ }^{\prime} ， B_{0}{ }^{\prime}, C_{0}{ }^{\prime}, a^{\prime}, b^{\prime}, c^{\prime}, \alpha^{\prime}, r^{\prime}=$ 一般化 BWR 式の 8 定数 $\boldsymbol{d}=$ 密度 $[\mathrm{g} \cdot \mathrm{mol} / \mathrm{cc}]$

$d_{r}=\left(d R T_{c}\right) / P_{c}[-]$

$d_{V}{ }^{0}, d_{L}{ }^{0}=$ 純粋物質の䅆和状態における気，液各相の実測密 度 $[\mathrm{g} \cdot \mathrm{mol} / \mathrm{ccc}]$

$f$ フフガシチ $[\mathrm{atm}]$

$f_{V^{0}}, f_{L^{0}}=d_{V^{0}}, d_{L^{0}}$ から式 (8) により計算した気, 液各相 のフガシチ

$K_{i}=$ 気液平衡比 $=y_{i} / x_{i}$

$M_{i j}=$ Orye による修正 BWR 式中の，定数 $A_{0}$ に関する修 正因子

$P=$ 圧力 $[\mathrm{atm}]$ 
$P_{c}=$ 臨界压力 $[\mathrm{atm}]$

$P_{\text {cal }}=\mathrm{BWR}$ 式により求まる飽和蒸気压 [atm]

$P_{r}=$ 対臨界圧力 $[-]$

$P_{s}=$ 実測の飽和蒸気圧 $[\mathrm{atm}]$

$P_{V}{ }^{0}, P_{L}{ }^{0}=d_{V^{0}}, d_{L}{ }^{0}$ から式（1）により計算した気, 液各相 の圧力 $[\mathrm{atm}]$

$R=$ 気体定数 $\left[\mathrm{atm} \cdot l /{ }^{\circ} \mathrm{K} \cdot \mathrm{g} \cdot \mathrm{mol}\right]$

$T=$ 温度 $\left[{ }^{\circ} \mathrm{F}\right.$ または $\left.{ }^{\circ} \mathrm{C}\right]$

$T_{r}=$ 対臨界温度 $[-]$

$X_{i}=$ 混合物の液相中の $i$ 成分のモル分率 $[-]$

$\omega=$ Pitzer の偏心因子

引用文 路

1）荒井康彦，斎藤正三郎，前田四郎，第 8 回シンボジウム，講演前 刷集, 化学工学協会 (1969)
2) Benedict, M., Webb, G.B., Rubin, L.C., J. Chem. Phys., 8, 334 (1940).

3) ibid., Chem. Eng. Prog., 47, 419, 449 (1951).

4) Orye, R.V., Ind. Eng. Chem. Process Design and Develop., 8, (4), 579 (1969).

5) Edmister, W.C., Vairogs, J., Klekers, A.J., Am. I. Ch. E. $J ., 14,479$ (1968).

6) Canjar, L.N., Manning, F.S., "Thermodynamic Properties and Reduced Correlations for Gases", Gulf Publishing Company, Houston Texas.

7) Kay, W.B., J. Chem. Eng. Data, 15, 46 (1970).

8) Nysewander, C.N., Sage, B.H., Lacey, W.N., Ind. Eng. Chem., 32, 118 (1940).

9）平田光穗，須田精二郎，宮下礼子，星野俊男，第 12 回高压討論 会予稿集，112 (1970).

10）平田光穂, 須田精二郎，宫下礼子，星野俊男，第 4 回化学工学協 会秋季大会請演予稿集，139 (1970).

11) Pitzer, K.S., J. Chem. Phys., 1, 583 (1939).

\section{新刊紹介}

ГManagement and Automation in the Petroleum Industry $\rfloor$ : The Institute of Petroleum

IP (イギリス石油協会) の夏季大会は 1970 年 6 月 2 日 から5 日まで Bath（ロンドンの西方約 $150 \mathrm{~km}$ ）において 開催された。主題は「石油産業における経営と自動化」で， 電気学会, 機械学会, 化学学会, 計測制御学会と共催になっ ている。

本書はこの講演と討議の内容を完全に集録したもので，テ 一マは採掘 1, パイプライン 2 , タンカー 1 , OR 1 , 出荷 制御 2, 給油所 1 , 油そ弓所 1 ，八ードウェア 1 , 精製 1 , 化学 2 , その他総説的なもの 2 なと, 広範囲な内容加成。 ている。いす゚れもコンピューターを中心に，実際的に述べら れており，今日の計装・制御技術の諸問題をよくまとめてあ るので参考になると思われる。

イギリスの代表的プロセスコンピューターメーカーである Ferranti 社の Donkin 氏が, 第 3 世代といわれる今日のコ ンピューターの平均像をきわめて简潔にまとめているが; そ の後の討議において「真の目標と理由うけ（採算）」,「アナ ログ計装との対比」,「コンピューターの信頼性とパックアッ プ方法」などを鋭く突いており，われわれのかかえている問

題と全く同じであることから親近感を持たされた。 出版社 : Elsevier Publishing Co.

頁 数 : 286 ページ

発行年 : 1971 年

定 価: 4,800円

(三浦高弘)
「現代の石油化学」

\section{監修 功刀泰碩 \\ 編集 中山国男, 藤井 茂}

本書は現代の石油化学工業の実態を，世界的な広い視野に 立って解説したものであり，その内容は次のと括りである。

1. : 石油化学工業の概要

2. 石油化学の原料

3. 石油の化学原料化

4. 中間製品

5. 最終製品

6. 石油化学コンビナート

7. 石油化学工業の末来像

その中心を成すのは中間製品および最終製品についての解 説であるが，本書の特色は単なるハンドブック的性格に止ま らず，石油化学の世界的動向や政策面にまでも触れ，原料問 題と環境污染，さらには石油化学工業の未来像にまでも筆が 及ふとといらその広籁さにある。特に原料問題については，石 油の総合利用の観点から，各留分完全利用型モデルを含むケ ミカルリファイナリーの将来粠想に関する展望もなされてい て，きわめてユニークな解説書といえる。

国内 17 個所の石油化学コンビナートについてもその発展 の経緯ならびに現状の害鹪が要領よくまとめられている。

平易な記述に上り，専門的事項も理解が容易なように配慮 されているため，石油および石油化学関係者には座右のハン ドブックとして，その他一般の事務系綪の方々にも恰好の手 引書としてきわめて有用なる書といえる。

発 行 所: 横川書房

$$
\begin{aligned}
& \text { ページ数 : } 580 \text { ページ } \\
& \text { 定 価 : } 2,500 \mathrm{円}
\end{aligned}
$$

（尾崎博巳） 